\title{
THE INFLAMMATORY REACTION OF PULP TISSUE WITH CALCIUM HYDROXIDE, MTA AND PORTLAND CEMENT (In Vivo)
}

\author{
Jos Erry Hesti Witasari*, Usman Munyati ${ }^{* *}$, Anggraini Dewi ${ }^{* *}$
}

Keywords:
inflammatory reaction of
pulp; calcium hydroxide;
MTA; Portland Cement.

\begin{abstract}
Background : Perforation in normal pulp could be happened anytime. In sterile condition, direct pulp capping was the right therapy to maintain the vitality and pulp function. Direct pulp capping agent must contact with the pulp tissue. Generally, body had an immunologic respond with foreign body that contact with tissue. The respond could be inflammatory reaction. The used direct pulp capping agents were calcium hydroxide, and Mineral Trioxide Aggregate (MTA) which known as better agent but relatively expensive and difficult to obtain. So that, the alternative of MTA, Portland cement which was the same essential of MTA, was being developed. The aim of this study, to analized inflammatory reaction of the pulp tissue with direct pulpcapping agents calcium hydroxide, MTA, and Portland cement.
\end{abstract}

Methods: Free caries M. Nemestrina's posterior teeth were prepared to form pin point perforations on buccal surface of the crowns. The teeth were applied with one of the three capping agents. Teeth were filled and extracted. The extracted teeth were proceed into histopatological preparation slides to evaluate the inflammatic reaction.

Results: The result showed no statistically significant differences of pulp inflammatory reaction between calcium hydroxide, MTA and Portland cement in $7,14,42$, and 90 days.

Conclusion: The inflammatory reaction of pulp tissue of the three pulp capping agent (calcium hydroxide, MTA, and PC) were insignificant different.

\section{INTRODUCTION}

In Indonesia, the endodontic case was the highest problems in dentistry. Based on Health Department profile in 1999, the endodontic cases in hospital became $47.83 \%$, and in the public health center became $49,90 \% .^{1}$ In research said that the highest frequency of pulp disease distribution in Integrated clinic of Dental Hospital Dentistry faculty, University of Indonesia, was reversible pulpitis in average $45 \%{ }^{2}$ Another research, said that beside bacteria, exposed pulp could caused by traumatic factor and iatrogenic factor during proceduring cavity preparations. These factors could lead an inflammation reaction of the pulp. The reaction, caused by those factors and the agent, was needed for the vital pulp therapy. ${ }^{3}$

Ingeneral, body has an immunologic respond with foreign body that contact with the tissue. The respond could be an inflammatory reaction which known as defences reaction of body with danger stimuli, or it was called irritance. ${ }^{4}$ In principle, There was three important things that happened in inflammatory reaction. First, there was increasing blood flow that leucocyte and protein serum flew to the inflammation area. Second, there was increasing the capillary permaebility to exudate the protein serum that was needed to control infection. And third,

\footnotetext{
${ }^{*}$ Departement of Conservative Dentistry University of YARSI, ${ }^{* *}$ Departement of Conservative Dentistry University of Indonesia

Korespondensi: hesti.witasari@gmail.com
} 
there was increasing migration of leucocyte into the tissue. ${ }^{5}$

It said that there was dendritic cell in normal pulp that has an important action of the mechanism of pulp inflammatory reaction caused by an antigen. Although dendritic cell could not be able to identify foreign antigen specifically, this cell was able to send an emergency signal to activate the limphocyte $T$ cell that could lead the immunocompetent cells to build a defences local immunity of the pulp. ${ }^{6}$

Based on the principle of endodontic treatment, It is important to reach the perfect healing, because the pulp need to gain back the healthy and the functional of pulpodentinocomplex in vital exposed pulp case. ${ }^{7}$ Human pulp has the capacity of healing which is the intrinsic pulp respond, as long as germfree. ${ }^{8}$ another research showed that a big accumulation of PMN(Polimorphonucleus) cell usually indentify an infection that could lead to the risk of necrotic pulp. However, in germfree condition, pulp condition which was being inflammation could have perfect healing process potention. It means that inflammation condition do not always lead to be unsuccess treatment, but it can be an initial healing process after applicating the agent for vital pulp therapy. ${ }^{3}$

In vital pulp therapy, direct pulp capping is an adequate treatment for conserving the vitality and function of the pulp. ${ }^{7}$ Many agents have been applicated for direct pulp capping treatment. Calcium hydroxide was usually used to be the pulp capping agent. Calcium hydroxide is a strong alcali so that it could lead to a local necrotic in surface tissue of the pulp. However, some researchs said that this pulp capping agent is not able to build a perfect dentinal bridge, and there was still have a medium inflammation condition. And it showed that the chronic inflammation could inhibit the healing process.

Another agent, known able to induct minimal inflammatory infection and potent to induct faster healing process, is MTA (Mineral trioxide aggregate). In research said that the application using Calcium hydroxide agent better replace with MTA agent, because in histologic assessment, inflammatory reaction is more minimal than Calcium hydroxide. And the dentinal bridge is built thicker and better than Calcium hydroxide. ${ }^{9}$

Although this agent is better significantly than calcium hydroxide, it is still difficult to find and still expensive. Therefore, the reseachers move to research Portland cement agent, which is the MTA based material, as the alternative agent. Portland cement, containing tricalcium silicate, dicalcium silicat, tricalcium aluminate, calcium sulphate, is an agent that is usually used as building material. It is easy to find and quite cheaper than MTA. ${ }^{10}$ Some researches of Portland cement were already done. In those researchs were known that there was character similarity with two others agents. The aim of this study, to analized inflammatory reaction of the pulp tissue with direct pulp capping agents calcium hydroxide, MTA, and Portland cement.

\section{METHODS}

The animal quarantine section

This reseach used Rhesus Maccaca Nemestrina or monkey, which was 6-8 years old with 10-12 kgs weight, as the subject research. The quarantine section was done about 1-3 months and always test TBC (Tuberculosis) two times in two weeks. Animals was prevented by infection diseases. And they were gave proporsional food and drink. The Identification of the animals were made with ID number. 
The animal preparation section

Before doing the experiment, the animal did not eat and drink in 10 hours. And sedation drugs (20 mg/BW ketamin hydrochloride) was given intramuscularly. Then, the vital signs were observed.

The experimental section in the animal

Free caries M. Nemestrina's teeth were treated with scaler, polished with rubber cup, and cleaned with desinfectant agent (povidine iodine). The region of the tooth was isolated by sterile cotton roll, and the saliva was control by the high speed evacuation. The teeth were prepared to form pin point perforations on buccal surface of the crowns. After sterilizing the cavity and dry it, the teeth were applied with one of the three capping agents, and then they were filled. We used 36 teeth which is devided into three groups of pulp capping agents. First group is Calcium hydroxide agent group, Second group is MTA agent group, and third is Portlan cement group. In each group, there is 12 teeth which is devided into 4 sections. Each group is sectioned by the time ( 7 days, 14 days, 42 days, and 90 days). So, in one section is containing three teeth. Also we take one teeth as a negative control, after perforated and filled with zinc oxide eugenol, then be microscopic evaluated after 7 days. Based on the time, the extracted teeth were proceed into histopatological preparation slides to evaluate the inflammatic reaction.

\section{The Data Analysis}

The data were being analysis with analytic statistic based on histopatologic condition. This condition was evaluated in each group used chisquare test for negative or positive appearance of inflammation by the time. And McNemar correlation test to evaluate the relation between the inflammation and the time.

\section{RESULT}

The analizing statistic about inflamatory

Table 1. The comparison of inflammatory reaction of three groups (Calcium hydroxide, MTA, and Portland cement) in 7 days.

\begin{tabular}{llll}
\hline Group & No inflammation & Inflammation & Total \\
\hline $\begin{array}{l}\text { Calcium } \\
\text { hydroxide }\end{array}$ & $3(100 \%)$ & $0(0 \%)$ & $3(100 \%)$ \\
MTA & $2(66,7 \%)$ & $1(33,3 \%)$ & $3(100 \%)$ \\
$\begin{array}{l}\text { Portland } \\
\text { cement }\end{array}$ & $2(66,7 \%)$ & $1(33,3 \%)$ & $3(100 \%)$ \\
\hline
\end{tabular}

Table 2. The comparison of inflammatory reaction of three groups (Calcium hydroxide, MTA, and Portland cement) in 14 days.

\begin{tabular}{llll}
\hline Group & No inflammation & Inflammation & Total \\
\hline $\begin{array}{l}\text { Calcium } \\
\text { hydroxide }\end{array}$ & $3(100 \%)$ & $0(0 \%)$ & $3(100 \%)$ \\
MTA & $1(33,3 \%)$ & $2(66,7 \%)$ & $3(100 \%)$ \\
Portland cement & $1(33,3 \%)$ & $2(66,7 \%)$ & $3(100 \%)$ \\
Total & $5(55,6 \%)$ & $4(44,4 \%)$ & $9(100 \%)$ \\
\hline
\end{tabular}


Table 3. The comparison of inflammatory reaction of three groups (Calcium hydroxide, MTA, and Portland cement) in 42 days.

\begin{tabular}{llll}
\hline Group & No inflammation & Inflammation & Total \\
\hline $\begin{array}{l}\text { Calcium } \\
\text { hydroxide }\end{array}$ & $1(33,3 \%)$ & $2(66,7 \%)$ & $3(100 \%)$ \\
MTA & $1(33,3 \%)$ & $2(66,7 \%)$ & $3(100 \%)$ \\
$\begin{array}{l}\text { Portland } \\
\text { cement }\end{array}$ & $2(66,7 \%)$ & $1(33,3 \%)$ & $3(100 \%)$ \\
Total & $4(44,4 \%)$ & $5(55,6 \%)$ & $9(100 \%)$ \\
\hline
\end{tabular}

Table 4 . The correlation of inflammatory reaction between 7 days and 14 days.

\begin{tabular}{llll}
\hline Group & No inflammation & Inflammation & Total \\
\hline 7 days & $7(77,8 \%)$ & $2(22,2 \%)$ & $9(100 \%)$ \\
14 days & $5(55,6 \%)$ & $4(44,4 \%)$ & $9(100 \%)$ \\
\hline
\end{tabular}

Table 5 . The correlation of inflammatory reaction between 14 days and 42 days.

\begin{tabular}{llll}
\hline Group & No Inflammation & Inflammation & Total \\
\hline 14 days & $5(55,6 \%)$ & $4(44,4 \%)$ & $9(100 \%)$ \\
42 days & $4(44,4 \%)$ & $5(55,6 \%)$ & $9(100 \%)$ \\
\hline
\end{tabular}

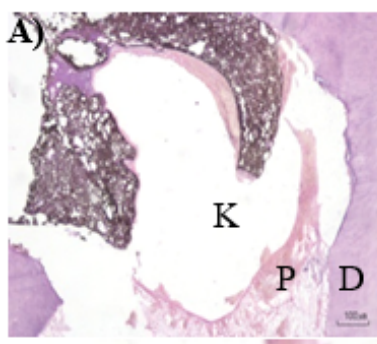

D)
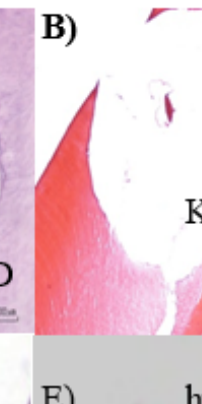

E)
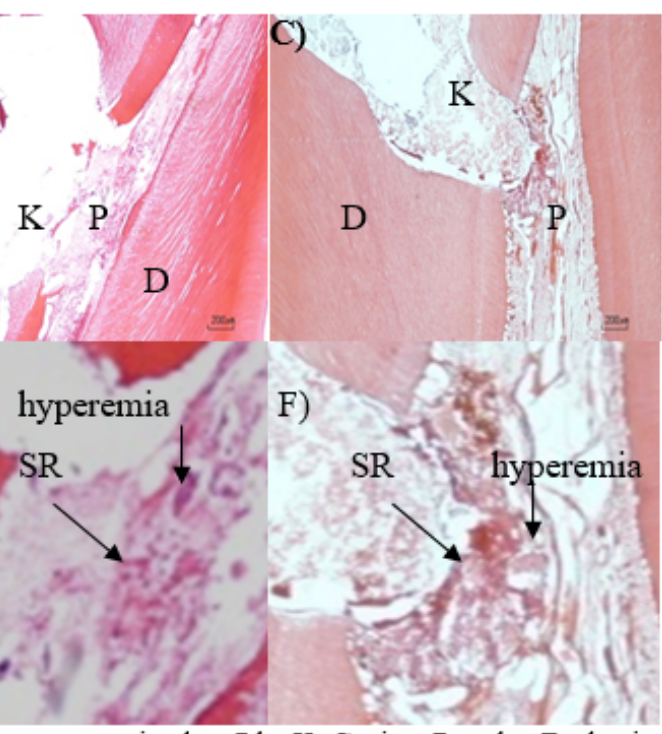

Picture 1. Histopatologic pulp tissue appearence in day 7 th. $\mathrm{K}=$ Cavity, $\mathrm{P}=$ pulp, $\mathrm{D}=$ dentin, $\mathrm{SR}=$ cells of inflammation. $\mathrm{A}, \mathrm{D}$ pictures was no inflammation in Calcium hydroxide group. $\mathrm{B}, \mathrm{E}$ pictures, there was inflammation in exposed pulp area of MTA group, seemed like bulging of inflammation cells and blood vessels hyperemia. $C_{2} \mathrm{~F}$ pictures, there was inflammation in the exposed pulp area seemed like bulging of inflammation cells and blood vessels hyperemia. 


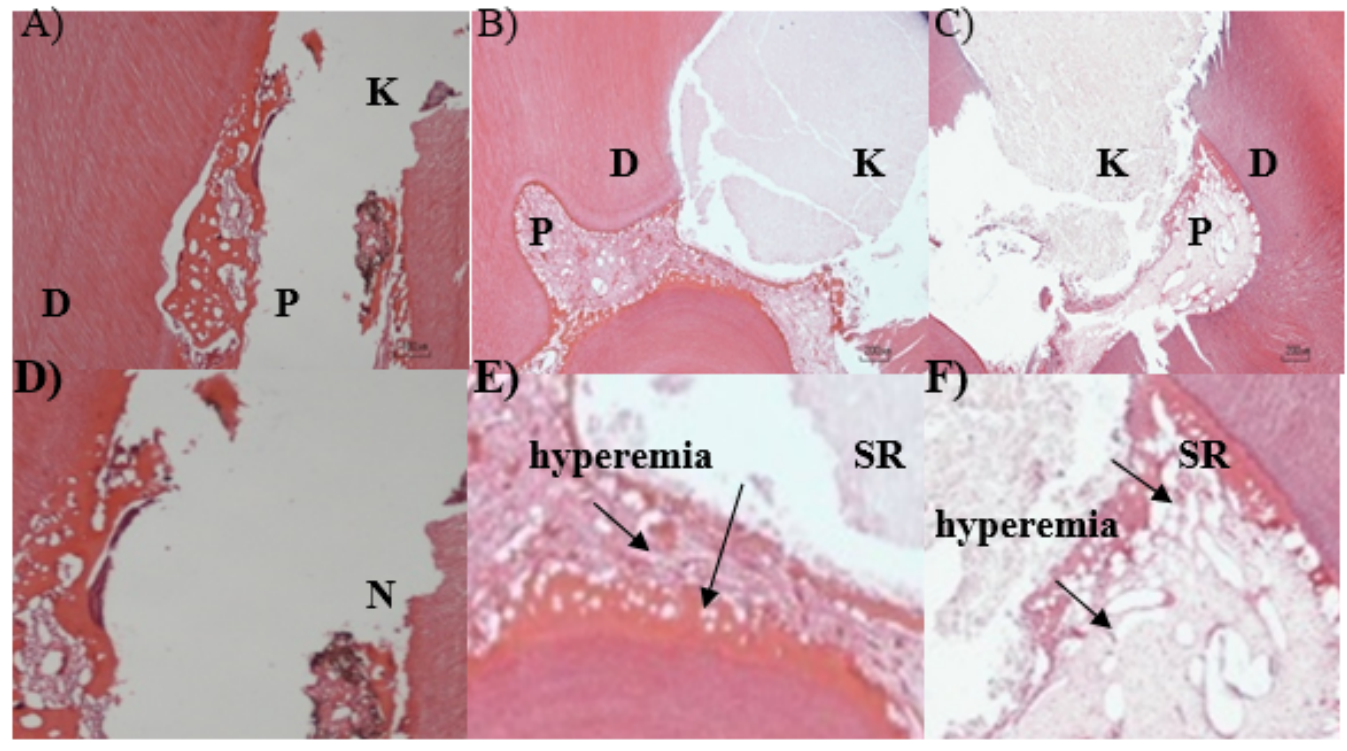

Picture 2. Histopatologic pulp tissue appearence in day 14th. $\mathrm{K}=$ Cavity, $\mathrm{P}=\mathrm{pulp}, \mathrm{D}=$ dentin, $\mathrm{SR}=$ cells of inflammation. $\mathrm{A}, \mathrm{D}$ pictures was no inflammation in Calcium hydroxide group. $\mathrm{B}, \mathrm{E}$ pictures, there was inflammation in exposed pulp area of MTA group, seemed like bulging of inflammation cells and blood vessels hyperemia. C,F pictures, there was inflammation in the exposed pulp area seemed like bulging of inflammation cells and blood vessels hyperemia.

proportion in three agents groups (Calcium hydroxide, MTA, and Portland cement) in 7 days, 14 days, and 42 days are written on the tables. In table 1 , The result showed that in 7 days, there is no inflammation in
Calcium hydroxide group, and there is $33,3 \%$ inflammation in two others group. In table 2 , the result showed that in 14 days, there is no inflammation in Calcium hydroxide group, and there is inflammation $66,7 \%$ in two others

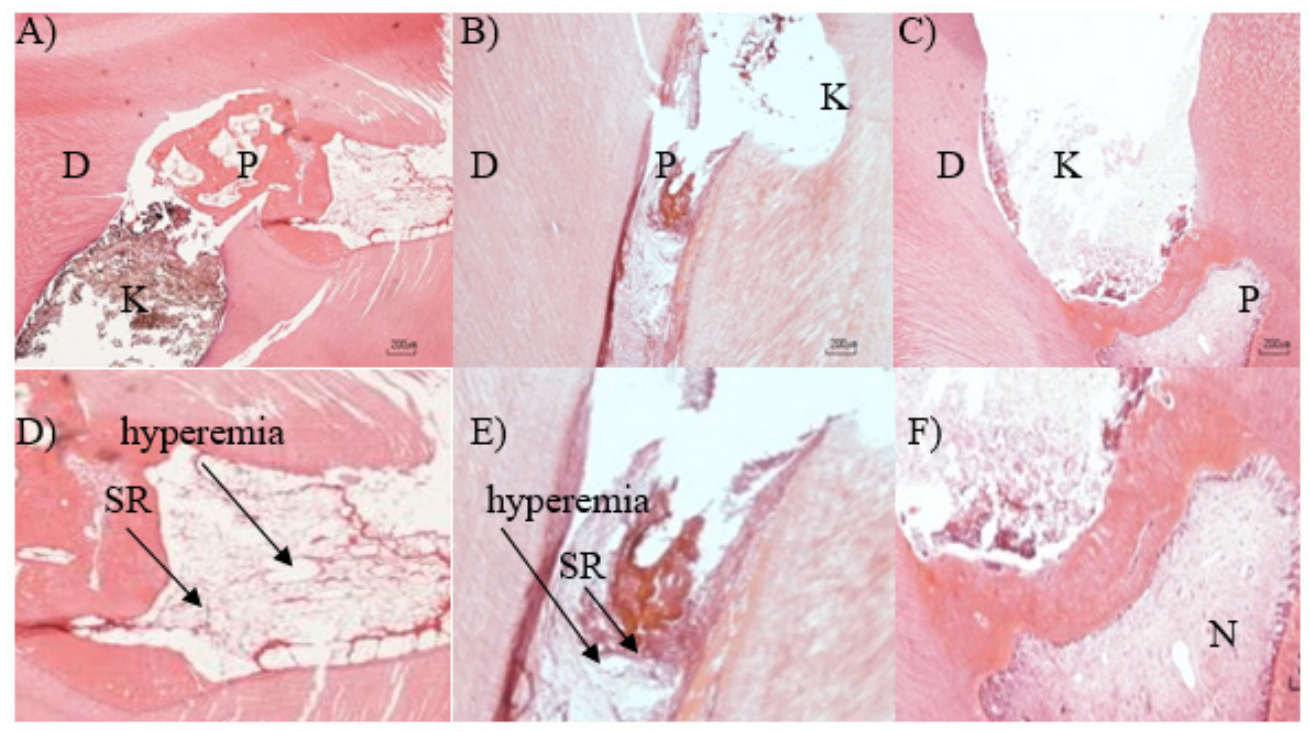

Picture 3. Histopatologic pulp tissue appearence in day 42 th. $K=$ Cavity, $P=p u l p, D=$ dentin, $\mathrm{SR}=$ cells of inflammation. A,D pictures were an inflammation in Calcium hydroxide group, seemed like bulging of inflammation cells and blood vessels hyperemia. B,E pictures, there were inflammation in exposed pulp area of MTA group, seemed like bulging of inflammation cells and blood vessels hyperemia. $\mathrm{C}, \mathrm{F}$ pictures was no inflammation in the area of the pulp. 


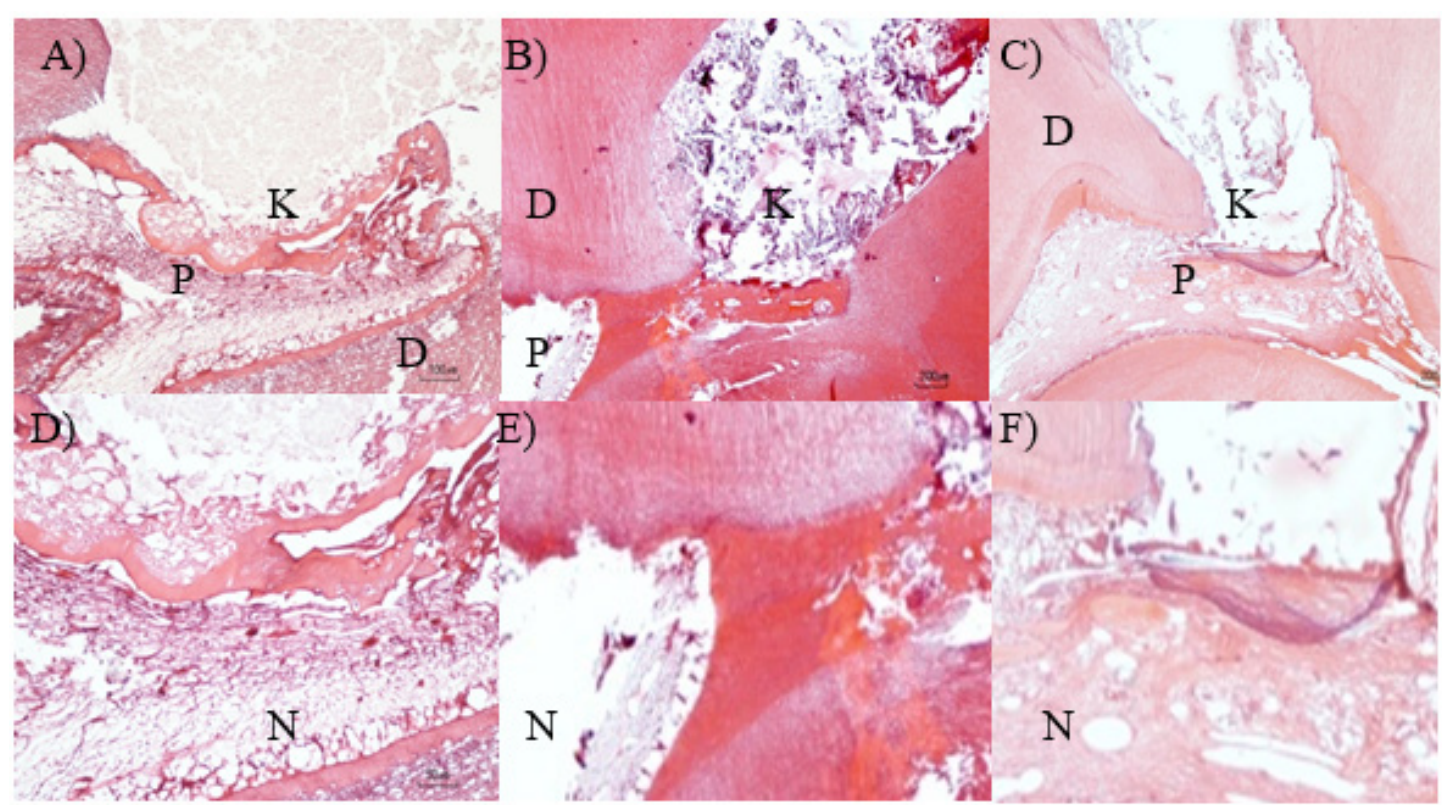

Picture 4. Histopatologic pulp tissue appearence in day 42 th. $\mathrm{K}=$ Cavity, $\mathrm{P}=\mathrm{pulp}, \mathrm{D}=$ dentin, $\mathrm{SR}=$ cells of inflammation, $\mathrm{N}=$ Normal. $\mathrm{A}, \mathrm{D}$ pictures were no inflammation in Calcium hydroxide group. B,E pictures, there were no inflammation in exposed pulp area of MTA group. C,F pictures was no inflammation in the area of the pulp.

group. In table 3, the result showed that in 42 days, there is $66,7 \%$ inflammation in Calcium hydroxide and Portland cement group, and there is inflammation $33,3 \%$ in MTA group. In 90 days, it can not be counted statistically because there is no inflammation appearance in all groups. In table 4, there is a difference of inflammation between 7 days and 14 days. But there is no significant difference statistically. In table 5 , there is a difference of inflammation between 14 days and 42 days. But there is no significant difference statistically.

\section{DISCUSSION}

This research used maccaca nemesrina or monkey, because this animal species was easy to find. And the type and the amount of teeth were the same with the human teeth.

From the results presented above, it is said that the percentage of inflammation at day 7 was known that there was inflammation in the Portland cement group and the MTA material was as much as $33.3 \%$ of the total sample of each group. However, the statistical test showed no significant differences between groups of materials. This was probably caused by the presence of an inflammatory reaction in response to immunologically different in each individual. Other research suggested that a substance that caused the foreign body respond indicated the accumulation macrophage and possibly the formation of multinucleated giant cells. ${ }^{4}$

At day 14 there was also inflammation of the MTA and the SP as much as $66.7 \%$, indicating that the MTA and SP showed a more prominent inflammatory compared with calcium hydroxide, although the difference was statistically no significant difference. This result was related with research of Ricardo which stated that at days 7 and 14 , the dominant 
inflammatory reaction seen on MTA materials and SP were planted in the subcutaneous of rat tissues. ${ }^{11}$ It was likely also caused by structure of the MTA and Portland cement particles finer than the calcium hydroxide so that the surface area exposed pulp was more extensive so the reaction occurs more rapidly than calcium hydroxide. And the principle of MTA and Portland cement was also similar to calcium hydroxide which initially causes the tissue to contact with the occurrence of coagulation necrosis due to an increase in the $\mathrm{pH}$ reached 9-10. ${ }^{12}$

At the day-42, there was visibled inflammation at all three agents, that the calcium hydroxide and MTA as much as $66.7 \%$, whereas in $33.3 \%$ Portland cement. Seen the greatest percentage of inflammation, especially in the calcium hydroxide and MTA. While it seen decreasing in the percentage inflammation of Portland cement. On day 42 , the newly calcium hydroxide showed an inflammatory reaction whereas the MTA and Portland cement materials reaction have been seen since day 7 th. This could be assumed that the work system MTA and Portland Cement induced tissue faster than calcium hydroxide. This was consistence with the statement that the MTA had effects that work faster in forming the hard tissue than calcium hydroxide. Although the calculations were not statistically significantly different. It was likely also caused by the limited number of samples.

On day 90, there was no inflammatory reaction in the whole sample. It was concluded that at this time there was a process of healing and expected to have a process of forming the dentinal bridge. On the relationship between time, there was no significant difference in inflammatory percentage changes. However, it was assumed that each time there wass a difference in the development of inflammation and inflammatory percentage, it lost on day 90 in all samples. In this study, there were no significant differences in the correlation between the time. It was also caused by a minimal number of samples in each group.

\section{CONCLUSION}

Inflammatory reaction in the pulp tissue exposed to agents calcium hydroxide, MTA, Portland cement had no significant difference, however, it is seen in the percentage of MTA and Portland cement at first inflamed than calcium hydroxide in seven days. Inflammatory reaction of pulp tissue to Portland cement had the smallest percentage in comparison with calcium hydroxide and MTA on the day forty-two, despite of no significant difference. Materials Calcium hydroxide, MTA, and Portland cement showed the healing effects of the pulp with marked loss of the inflammatory reaction on day ninety.

\section{REFERENCES}

1. Soerono A. Endodontologi: kumpulan naskah 19912003. Jakarta: Percetakan Hafizh. 2003:5.

2. Putri. Distribusi frekuensi penyakit pulpa pada pasien yang datang ke klinik integrasi RSGMP FKG UI Maret-Juni 2007. Jakarta: Universitas Indonesia. 2007. [Skripsi].

3. Henry F Duncan, PN Ramachandran Nair, Thomas R Pitt Ford Vital pulp treatment: a review. ENDO (Lond Engl) 2008;2(4):247-258

4. Trowbridge O., Emling C. :Inflammatian A review of the process. 5th ed, 1997.

5. Roit, Brostoff, Male. : Immunology. 6th, 2001.

6. Jontell M, Okiji U, Bergenholtz. Immune Defense Mechanisms of the Dental pulp. Crit. Rev.Oral Biol. Med. 1998; 9;179.

7. Seltzer S, Bender IB : The dental pulp. 2nd ed, W.B.Lippincott Philadelphia, 1975: 150,162,252335.

8. Barbosa AVH, Sampaio GC, Gomes FA, de Oliveira DP, de Albuquerque DS, Sobral APV. Short-term analysis of human dental pulps after direct capping with Portland cement. Open dentistry journal. 2009; 
3:31-35.

9. Parolia A, Kundabala M, Rao NN, achsry SRA, Agrawal P, Mohan M, Thomas M. A comparative histological analysis of human pulp following direct pulp capping with Propolis, mineral trioxide aggregate and Dycal. Australian Dental Journal 2010; 55: 59-64.

10. Camilleri J, Montesin F, Di Silvio, Pitt Ford TR. The cemichal constitution and biocompatibility of accelerate Portland cement for endodontic use. Int Endod J. 2005;38:834-42

11. Ricardo M, Maria L, Gabriel A, Julia W, Carolina C, Daniel R. Rat subcutaneous tissue response to modified Portland Cement, a new mineral trioxide aggregate. Braz. Dent. J. vol.20 no.2. 2009.

12. Lourde M, Holland R, Reis A, Marcelo C, Sueli S, Dezan E, Souza V, Alessandro LD. Evaluation of Mineral Trioxide Aggregate and Calcium Hydroxide Cement as pulp-capping Agents in Human Teeth. J Endod 2008;34:1-6. 